invited to attend the International Congress. Those outside the United States expecting to be present are requested to inform the General Secretary (Dr. R. C. Evans, Crystallographic Laboratory, Cavendish Laboratory, Cambridge, England) at a very early date in order that detailed planning may proceed without delay; those willing to contribute papers should at the same time forward details for consideration by the Programme Committee. Crystallographers in the United States will receive separate notification from the American Society for X-ray and Electron Diffraction or the Crystallographic Society of America. It will not be possible for the Union to provide funds to assist delegates in attending the Congress, and crystallographers should therefore make their own arrangements in this matter.

\section{Bristol Symposium on Cosmic Rays}

THE Colston Research Society, which for many years has made grants in aid of research in the University of Bristol, proposes to support a series of symposia, to be held annually, on selected topics of scientific importance. Papers will be invited from distinguished guests and it is proposed that each year a volume giving an account of the proceedings, including discussions, will be published. The first symposium will be on "Cosmic Radiation", and will be held in the H. H. Wills Physical Laboratory, University of Bristol, during September 20-24, 1948. It will be possible to accommodate a limited number of members of the symposium in Wills Hall, University hall of residence. Further information can be obtained from Dr. C. F. Powell, H. H. Wills Physical Laboratory, Royal Fort, University of Bristol.

\section{Speech Therapy Conference}

A Speech Therapy Conference, arranged by the College of Speech Therapists, 68 Queen's Gardens, London, W.2, will be held during September 20-24 at the house of the Royal Society of Medicine. There will be sessions on the following subjects: the aim and scope of speech therapy, the emotional back. ground of stammering, speech disorders arising from head injuries, the speech clinic and the speech-defective child, and the role of emotional problems in producing disorders of speech. Summaries of proposed papers must reach the Secretary not later than March 1. It is hoped to inaugurate during the Conference an International Federation of Speech Therapists. Further information can be obtained from the Conference Secretary, College of Speech Therapists, 68 Queen's Gardens, London, W.2.

\section{Conference on the Family}

A conference on "The Family: Whose Responsibility ?" is to be held under the auspices of the British Social Hygiene Council and the Town and Country Planning Association in the Conway Hall, Red Lion Square, London, W.C.1, during February 10-11. The chairman of the conference will be Mr. Ivor Thomas, M.P., and chairmen of the various sessions includ॰ Dr. Letitia Fairfield, Mr. Walter Raeburn and Sir Anderson Montague-Barlow. Speakers will include Mr. Maurice Reckitt, Dr. Mary Smith, Dr. William Moodie, Miss W. M. Crossman, Mr. B. G. H. Brooke-Taylor, Sir Wilfrid Garrett and Dr. Macalister Brew. Further information can be obtained from the Secretary, British Social Hygiene Council, Tavistock House North, Tavistock Square, London, W.C.2.

\section{Summer School in Micro-Chemical Techniques}

IN view of the interest shown in the Summer School in Micro-Chemical Techniques held at the Queen's University, Belfast, in 1947, the course will be repeated this year in a somewhat amplified form during June 21-July 3. Lectures will be given together with demonstrations and practical work on standard inorganic microchemical techniques. In addition, limited provision is being made for instruction in selected topics such as physico-chemical measurements on small quantities of material, use of the microscope and micro-electrolytic methods.

\section{Awards for Scientific Journalism}

THE American Association for the Advancement of Science - George Westinghouse Science Writing Awards for 1947 have been presented to George A. Keaney, feature writer on the New York World. Telegram, for his series of five stories on blood, and more especially on the $R h$ factor of blood, which appeared in the New York World-Telegram, March 18-22, 1947 ; and to Steven M. Spencer, associate editor of the Saturday Evening Post, for his article, "New Hope for the Anemic" (dealing with folic acid), which appeared in the December 14, 1946, issue of that journal. An honourable mention for the Magazine Writing Award was given Lorus J. and Margery J. Milne, free-lance writers, for their article, "The Life of the Water Film", published in the June 1947 issue of Natural History. The two awards, of 1,000 dollars each, are available from funds provided by the Westinghouse Educational Foundation of the Westinghouse Electric Corporation and under the administration of the American Association, and are made in an effort to stimulate and maintain a high standard of science reporting for the lay public through newspapers and general magazines.

\section{Announcements}

UNDER the provisions of Rule II of the Athenæum, which empowers the annual election by the Com. mittee of a certain number of persons of dis. tinguished eminence in science, literature or the arts, or for their public services, the following have been elected members of the Club : Lord Jowitt, Lord Chancellor; Sir Alexander Fleming, professor of bacteriology, University of London; Sir Oliver Franks, provost of Queen's College, Oxford.

DR. R. L. Sмттн-Rose, superintendent of the Radio Division of the National Physical Laboratory, has been appointed to the new post of director of radio research in the Department of Scientific and Industrial Research. He will be in charge of the radio research work of the Department, for which a new station will eventually be established. The new station will incorporate the work now being carried out in the Radio Division of the National Physical Laboratory, and the Radio Research Station of the Department of Scientific and Industrial Research at Slough, and also work at present being done for the Department at the Telecommunications Research Establishment at Malvern.

Prof. Frederick R. Miller, professor of physiology in the Faculty of Medicine, University of Western Ontario, has been appointed research professor of neurophysiology in the University.

Dr. R. E. G. Armatroe, director of the Lomeshie Research Centre, Londonderry, has been given a Viking Fund award of about 3,000 dollars to enable him to undertake a field trip to West Africa this year. 